Inna Fedotenko

ORCID: 0000-0003-1160-6334

Tula State Lev Tolstoy Pedagogical University

Tula, Russia

Irina Yugfeld

ORCID: 0000-0002-7784-1751

Moscow City Pedagogical University

Moscow, Russia

\title{
IMPLEMENTATION OF INCLUSION IN HIGHER EDUCATION
}

\author{
https://doi.org/10.34739/sn.2021.21.01
}

\begin{abstract}
The authors consider the ways and means of implementing the idea of inclusion in the university educational process. The researchers have included information on the history of inclusion, on various models of inclusive education, and on the specifics of a family with a child with special educational needs in the content of psychological and pedagogical disciplines, as well as elective courses. The authors have introduced new tasks of teaching practice, with students describing conflicts, bullying, mobbing, and school violence in traditional and inclusive classrooms. Students have been asked to justify their intended actions, which could prevent potential risks and find a competent way out of a difficult situation. Plot-role-playing games and group discussions held in student groups on the problems of "special" children and migrant schoolchildren have also facilitated implementation of the idea of inclusion. Discussion teaches future teachers to coordinate positions, values, to make decisions, and helps them see new personal meanings. Students' daily communication at the university with physically or mentally challenged mates with students of different cultures, faiths, and languages has played a significant role in their acceptance of inclusion.
\end{abstract}

Keywords: inclusion, students with special educational needs, preparedness for professional activity, dialogue, game technologies, teaching practice

\section{Introduction}

In Russia over the past decade, for objective and subjective reasons, there has been a significant change in the attitude of society to physically and mentally challenged people and to the assessment of the poten- 
tial of children with special educational needs. A kind of reassessment of priorities has also affected the teaching community: most teachers are convinced that every child, regardless of their state of health, has the right to receive a quality education. The professional and pedagogical environment evaluates inclusion as a social and personal need of a special child but not as a fashion trend. The actualization of the issue of preparing future teachers for professional activity in the conditions of inclusion is associated with an unfavorable prognosis regarding the mental and physical health of children and adolescents. There is a clear trend of deterioration in school children's health, a rapid increase in the number of children with disabilities. The organization of high-quality education of children with different potential opportunities is the psychological and pedagogical basis for the system of future "social elevators". The school today needs a teacher who is not only convinced of the value of inclusion, but also knows how to put its ideas into practice.

In the educational organizations of the Tula region today, almost every classroom represents an inclusive space. In the Russian tradition, inclusion is mainly understood "in a narrow context" as the inclusion of physically or mentally challenged children in a single educational environment together with nondisabled peers. At the same time, the modern world presents inclusion in the "broad sense of the word," that is, the inclusion of children of different social strata, nationalities, faiths, migrant schoolchildren, and gifted children in the class space. Students from migrant families are children with special educational needs, they need support, the focus and content of which depends on specific problems. Inclusion is not limited to the formal joint presence in the same class of children with preserved psychophysical functions and children with certain disabilities. It is assumed not to ignore the specific needs of schoolchildren with developmental disabilities as they should be treated with comprehensive and careful consideration. Teachers should deeply understand the specifics of the emerging socio-psychological problems.

The concept of inclusive education in Russia is attracting new supporters who consider this option optimal: stereotypes regarding disability are being destroyed; children with special educational needs, as well as schoolchildren of various cultures, faiths, and languages are fully 
adapting to life in society, and the behavior of their nondisabled classmates is becoming more tolerant [Rangelova, Fedotenko, 2020, s. 418$-424]$.

Opponents of inclusion emphasize the unwillingness of the education system to implement inclusive education, noting the difficulties of materials (ramps, special equipment, special computer software) and problems of psychological nature. An unmanageable inclusive environment can provoke an increase in school violence, child deviation, a deterioration in the psychological climate, and an increase in cases of humiliating and abusive treatment of a child. The significant challenges which inclusion faces involve didactic and axiological risks, bullying, mobbing, a lack of competent specialists who are ready to analyze the state of a "special needs" child from the position of ambivalence, simultaneous assessment of opposite motives, feelings, actions, values, and relationships. The potential dangers of inclusive practice are most often associated with the teacher, with their inflexible role-playing behavior, rigidity, categoricality, and the presence of adult fears and prejudices about children with developmental problems [Rangelova, Fedotenko, 2020, s. 418-424; Fedotenko, Dement'yeva, Zakharuk, 2018, s. 37-42].

Simultaneously with the appropriation of the idea of inclusion, latent resistance on the part of some teachers and school psychologists increases. The objective reason for the protest mood is a lack of teachers' preparedness for a new type of professional activity and for a new responsibility that goes beyond their functional duties. Teachers and psychologists, for whom the values of inclusive learning have not become personally significant, are only able to formally perform organizational procedures, destroying the essence of inclusion in their professional behavior. Teachers often provoke conflicts between nondisabled and "special needs" children, turning the classroom space into a psychologically dangerous one, increasing schoolchildren's anxiety, fear, and distrust.

\section{Research problems}

Preliminary diagnostics carried out by bachelors and masters of education of Tula State Lev Tolstoy Pedagogical University have shown that 
more than $85 \%$ of secondary school teachers are not prepared for professional interaction in an inclusive space:

- they do not possess the necessary professional competencies (diagnostic, predictive, conflict management, design);

- they do not know how to specifically prevent socially dangerous behavior of schoolchildren;

- they do not know the specifics and typology of risks and conflicts in an inclusive space;

- they do not know how to prevent suicidal behavior and school violence in an inclusive environment.

Some experienced teachers have negative stereotypes about physically or mentally challenged schoolchildren and children from migrant families. During professional activities, by their behavior and facial expressions, teachers transmit pity, distrust, disgust, fear, and suspicion to children. The complexity of the restructuring the system of an experienced teacher's professional values is also associated with their overestimated self-esteem and professional deformities [Fedotenko, Dement'yeva, Zacharuk, 2018, s. 37-42].

The lack of resilient teachers in the classroom, narrowly focused specialists (typhlopedagogues, sign language teachers, speech pathologists) puts the subject teacher in front of the need to understand, at least in general terms, the specifics of the dysontogenesis of a physically or mentally challenged child as well as the peculiarities of the national and confessional culture of migrant schoolchildren.

The number one concern today is the purposeful satisfying training of future teachers able to successfully implement the educational process in inclusive classrooms. The teacher in the inclusive space acts, first of all, as a facilitator, helping to develop the subjectivity of each child. At the same time, the teacher needs a special tact, delicacy, humanistic orientation of the individual, tolerance, creativity, and preparedness to enter a reflexive position.

We consider the university student's age as the most sensitive for the formation of future teachers' attitudes towards children with special educational needs and migrant schoolchildren. University students' priorities are mobile, changeable, and can be adjusted by the teacher's tar- 
geted activity. Negative stereotypes about schoolchildren with special educational needs and about students from migrant and refugee families are less pronounced in the minds of young people.

To form the preparedness of graduates for professional activity in inclusive classes, in the content of psychological and pedagogical disciplines as well as elective courses, we included information about the specifics of inclusion, about the characteristics of a family with a developmentally challenged child, about indicators of school violence, and about the characteristics of a potential victim. When considering the inclusion issues in a broad context, information about the specifics of national psychology and the peculiarities of communication in various cultures presented at seminars by students from China, Vietnam, Afghanistan, Tajikistan, and others, has been useful.

While studying age, pedagogical, social, and special psychology, the students have considered methodological approaches to teaching children with special educational needs in a mainstream school. Future teachers have analyzed the dynamics of changes in the concept of "inclusive education", the inclusion history in international and domestic education, and the peculiarities of interaction between teachers and children with various types of dysontogenesis. Students have paid special attention to the study of the characteristics of families with children with developmental difficulties and the competent organization of their psychological and pedagogical support. To build a constructive relationship with the family, the teacher should know its social and cultural context, the style of education, and the specifics of the relationship with a child with disabilities. Family support is based on the preservation of the child's functions and capabilities, on positive changes in their development, and on avoiding fixation on existing violations. Pedagogical support contributes to the creation of psychological protection of the "special needs" child, to the development of one's faith in oneself, in one's strength and capabilities, and it reduces the level of fear, anxiety and suspicion of children and their parents. When communicating with parents, it is necessary to create a situation of dialogue, to remove internal tension, and to rebuild the initial position of parents (sometimes aggressive, offensive, sometimes defensive). 
The future teacher should know that families raising a "special" child are characterized by a complex of psychological, social, and pedagogical problems concerning the family as a whole. The situation of parents can be described as an "internal (psychological) and external (social) impasse." When parents learn about their child's disability, they react in a similar way: the first reaction is rejection, aggression, fear, and guilt. Parents are afraid for the future of the child, for his or her rejection by society. This is followed by feelings of guilt and overwhelm that they, the parents, may have caused the child's disability [Fedotenko, 2019, s. 101-107, Fedotenko, Dement'yeva, 2020].

Student groups held discussions on the following topics:

"L.S. Vygotsky's idea about the possibility of turning a defect into a talent: myth or reality"; "Migrant students in Russian schools: problem or resource"; "Inclusion and correction: pros and cons"; "Cooperation of a teacher with the family of a special needs child: challenges and risks"; "School violence in traditional and inclusive education"; "Why do teachers need information of a multicultural and interfaith nature?".

The discussion teaches future teachers to coordinate positions, values, and make decisions, and develops both interdependence and autonomy. Discussion of the issues of inclusive education allows students to expand the information field and helps them to see new personal meanings.

In connection with the increasing number of challenges related to bullying, mobbing, children's aggression, and school violence, particular attention has been paid to the development of conflictological competence of students. Taking into account the content studied in the courses of Social Psychology, Pedagogical and Age Psychology, and Conflictology we included the specifics of conflict in an inclusive space and selfregulation techniques in the elective course of Psychology of Inclusive Education. To provide each student with a subjective experience of solving nonstandard situations, game, project and training technologies have been used in the classroom. Plot-role-playing games, stimulating flexibility of behavior, and freedom of choice of various roles by the student include them in various systems of relations and teach them to act 
responsibly in alternative situations. The role-playing games used during laboratory and practical classes include "Conflict of adolescents on a national basis" and "Parent-teacher meeting in an inclusive classroom" [Fedotenko, 2019, s. 101-107].

The appeal to the future teachers' subjective experience of interaction with physically challenged people, to literary and artistic texts, and to television programs dedicated to the problems of special needs people has facilitated the formation of the emotional and value component of the students' psychological competence. A significant role in the students' acceptance of inclusion was played by their daily communication at the university with classmates who have problems with physical and mental health and with students of different cultures, faiths, and languages. Non-disabled students saw a high level of motivation in their classmates with disabilities, for whom education is a tool for improving social status. Higher education gives this category of students freedom to choose goals and the possibility of social demand and financial independence. The university has organized an information support and consultation center for students with disabilities. The activity of volunteer groups to help students of different cultures, faiths, and various languages has been intensified.

\section{Conclusions}

The tasks of pedagogical practice have focused on enriching future teachers' subjective experience of behavior in an inclusive environment. Among the tasks offered to students, there have been those related to recording and describing cases of school violence, conflicts, aggression, and bullying in inclusive classes. Students have been asked to justify their intended actions, which could prevent potential risks, or find a competent way out of a difficult situation.

It is important to develop the future teacher's willingness to interact with the psychological service with doctors, with parents of children in order to choose the optimal educational route that is adequate to the state of physical and mental health of the child.

Initially, the results obtained give us reason to assert that the implementation of the idea of inclusion at the university is a significant 
step towards a school that respects the rights of every child and creates conditions for preserving their physical and mental health and for successful socialization.

\section{Literature}

Zacharuk T., Czeluścińska B. (2016), Rol' prepodavatelâ v social'noj integracii i bor'be protiv isklûčeniâ v processe obučeniâ studentov, [v:] E. Rangelova (ed.), Teoriâ i praktika na psihologo-pedagogičeskata podgotovka na specialista v universiteta, Gabrovo, s. 567-578.

Rangelova È., Fedotenko I. (2020), Psihologo-pedagogičeskaâ podgotovka bakalavrov obrazovaniâ $k$ professional'noj deâtel'nosti v inklûzivnoj srede, [v:] E. Bekasova (ed.), Fundamental'nye i prikladnye problemy pedagogiki i psihologii v obrazovatel'nom i social'nom kontekste, Moskva, s. 418-424.

Dement'eva D., Fedotenko I., Zaharuk T., (2018), Formirovanie cennostnogo otnošeniâ budusih pedagogov-psihologov k rabote s det'mi s osobennymi obrazovatel'nymi potrebnostâmi, [v:] K. Podrezov (red.), Universitet XXI veka: naučnoe izmerenie, Tula, s. 37-42.

Fedotenko I. (2019), Podgotovka budusihih pedagogov k prevencii social'noj izolâcii "osobyh» škol'nikov, [в:] K. Marciniak-Paprocka (red.), Inkluzja społeczna, Synergia działań, Siedlce, s. 101-107.

Fedotenko I., Dement'eva D. (2020), Formirovanie cennostnogootnošeniâ u buduŝih pedagogov-psihologo $k$ detâm s ograničennymi vozmožnostâmi zdorov'â: inklûzivnyj kontekst, "Mir nauki. Pedagogika i psihologia”, Vol. 8, № 3. 